\title{
USIA MENARCHE, STATUS GIZI, DAN SIKLUS MENSTRUASI SANTRI PUTRI
}

\author{
Enno Fitriningtyas, Endang Sri Redjeki, Agung Kurniawan \\ Fakultas Ilmu Keolahragaan Universitas Negeri Malang \\ ennoningtyas95@gmail.com
}

\begin{abstract}
A female teenager, puberty is marked by beginning of menstruation, its called the age of menarche. Menstruation should have a reguler cycle that is 21-35 days. Teenagers with less or more nutritional status have the risk of menstrual cycle disorders. Currenly, the health condition in a religious boarding schools are not considered. Whereas most of female students are school-age tenaager, they will be the next generation, that their qualities must be prepared carefully. The purpose of this study is to know the correlation the age of menarche and nutritional status with the menstrual cycle female students in Nurul Huda a religious boarding school for moslem at Malang regency. This study is an correlational-quantitative studies with the cross sectional approach's. The samples are 50 female students chosen by purposive sampling technique. Data analysis is using the alternative test of chi square test i.e fisher test. The results showed that in the first, $74 \%$ female students have age menarche in the normal category (11-13 years old), 74\% have a normal nutritional status (BMI 18.5-25.0) and 68\% have a normal menstrual cycle (21-25 days). Second, the correlation test showed that there is no correlation between the age of menarche and menstrual cycle, with $p$-value $=0.082$ and there is a significant correlation between the nutritional status and menstruation cycle in female students, with $p$-value $=0.001(\alpha=0.05)$.
\end{abstract}

Keyword: menarche, nutritional status, menstrual cycle, female student

\begin{abstract}
Abstrak: Pada remaja putri, pubertas ditandai dengan permulaan menstruasi yang disebut dengan usia menarche. Menstruasi seharusnya memiliki siklus yang teratur yaitu 21-35 hari. Remaja dengan status gizi kurang ataupun lebih memiliki resiko terjadinya gangguan siklus menstruasi. Saat ini kondisi kesehatan di pondok pesantren masih dipandang sebelah mata. Padahal sebagian besar santri putri di pondok pesantren adalah remaja usia sekolah yang merupakan generasi penerus harapan bangsa yang kualitasnya harus dipersiapkan dengan sebaik-baiknya. Tujuan penelitian ini untuk mengetahui hubungan usia menarche dan status gizi dengan siklus menstruasi santri putri di Pondok Pesantren Nurul Huda. Desain penelitian yang digunakan adalah kuantitatif korelasional dengan pendekatan cross sectional. Jumlah sampel adalah 50 orang yang dipilih dengan teknik purposive sampling. Analisis data menggunakan uji alternatif chi-square yaitu uji fisher. Hasil penelitian adalah sebagai berikut: pertama, $74 \%$ mengalami menarche kategori usia normal (11-13 tahun), 76\% memiliki status gizi kategori normal (IMT 18,5-25,0) dan 68\% memiliki siklus menstruasi kategori normal (21-35 hari). Kedua, uji korelasi menunjukkan bahwa tidak ada hubungan yang signifikan antara usia menarche dengan siklus menstruasi santri putri, diketahui nilai $p$-value $=0,082$, sedangkan ada hubungan yang signifikan antara status gizi dengan siklus menstruasi santri putri $p$-value $=0,001(\alpha=0,05)$.
\end{abstract}

Kata Kunci: usia menarche, status gizi, siklus menstruasi, santri putri

Pubertas merupakan masa peralihan antara masa kanak-kanak menuju masa dewasa. Tidak ada batas yang tegas antara akhir masa kanak-kanak dan awal pubertas. Secara klinis pubertas mulai dengan timbulnya ciri kelamin sekunder, dan berakhir kalau sudah ada kemampuan reproduksi (Widyastuti dkk, 2009). Pada remaja putri, pubertas ditandai dengan permulaan menstruasi (menarche). Pada permulaan usia menarche, biasanya diikuti dengan menstruasi yang tidak teratur.

Pada perempuan dengan usia menarche lebih muda, dan perkawinan di bawah umur, membuat panjang rentang usia reproduksi perempuan dan berdampak pada banyaknya anak yang dilahirkan (Rikesdas, 2010). Dalam 100 tahun terakhir ini usia menarche telah bergeser ke usia yang lebih muda, dikarenakan meningkatnya kesehatan umum dan gizi (Widyastuti dkk, 2009). 
Sekarang usia gadis remaja pada waktu menarche bervariasi lebar, yaitu antara 10-16 tahun dengan rata-rata 12,5 tahun (Derina, 2011; Prawirohardjo, 2009).

Menstruasi biasanya dimulai antara umur 10-16 tahun tergantung pada berbagai faktor antara lain kesehatan wanita, konsumsi gizi dan status gizi (Simon dan Andrews, dalam Emilia, 2008). Menstruasi seharusnya memiliki siklus yang teratur. Siklus menstruasi adalah jarak antara mulainya menstruasi yang lalu dan mulainya menstruasi berikutnya. Panjang siklus menstruasi yang normal atau dianggap sebagai siklus yang klasik ialah 28 hari (Prawirohardjo, 2009). Hanya ada $10-15 \%$ wanita memiliki siklus 28 hari (Nugroho \& Utama, 2014). Siklus menstruasi dipengaruhi oleh beberapa faktor meliputi usia, status fisik, aktivitas fisik, status gizi, hormon dan lingkungan.

Selama ini telah diketahui bahwa wanita dengan status gizi kurang memiliki resiko terjadinya gangguan siklus menstruasi. Akan tetapi, gangguan siklus menstruasi juga ditemukan pada wanita yang mengalami obesitas (Dieny, 2014). Seorang wanita yang mengalami kekurangan maupun kelebihan gizi akan berdampak pada penurunan fungsi hipotalamus sehingga akan terjadi peningkatan frekuensi gangguan siklus menstruasi. Asupan gizi yang kurang akan mempengaruhi pertumbuhan fungsi organ tubuh, akan menyebabkan terganggunya fungsi reproduksi dan akan berdampak pada gangguan siklus menstruasi (Paath, 2005).

Status gizi dapat dikatakan sebagai suatu ukuran mengenai kondisi tubuh seseorang yang dapat dilihat dari

makanan yang dikonsumsi dan penggunaan zat-zat gizi di dalam tubuh (Almatsier, 2010). Data Global Nutrition Report (2014) menunjukkan bahwa Indonesia termasuk salah satu negara yang memiliki permasalahan gizi. Data Riskesdas tahun 2013 menunjukkan bahwa, prevalensi gizi lebih pada remaja umur 16-18 tahun mengalami peningkatan dari tahun 2007 yang semula hanya $1,4 \%$ menjadi $7,3 \%$, sedangkan berdasarkan data Riskesdas 2010, secara nasional obesitas didominasi oleh perempuan.

Pondok pesantren menjadi salah satu institusi yang harus mendapatkan perhatian penuh karena sebagian besar santri putri usia remaja di pondok pesantren tersebut adalah anak usia sekolah yang merupakan generasi penerus harapan bangsa yang kualitasnya harus dipersiapkan dengan baik (Sutardji \& Azinar, 2007). Pondok pesantren di Kabupaten Malang biasanya terletak pada lingkungan pedesaan. Santri putri di daerah pedesaan cenderung memiliki kesehatan reproduksi yang berbeda dari remaja pada umumnya. Salah satunya dari penelitian yang dilakukan oleh Ali et al. (2011) juga menemukan bahwa ada perbedaan signifikan antara panjang siklus menstruasi pada remaja di desa, dimana hanya ada $15 \%$ remaja putri yang mengalami siklus menstruasi yang teratur.

Hasil observasi pendahuluan didapatkan bahwa perilaku kesehatan santri putri masih rendah, seperti

bergantian menggunakan peralatan mandi dan jarang sekali melaksanakan olahraga. Minimnya fasilitas yang disediakan oleh pondok pesantren membuat santri putri harus mengantri panjang saat mandi dan tidur dengan cara bergabung dengan banyak santri putri lainnya. Penelitian Ainur Rofieq (2012) pada pondok pesantren di Kabupaten Malang didapatkan bahwa bahwa menu makan di pondok pesantren lebih sederhana dibandingkan dengan menu mereka saat di rumah. Padahal frekuensi makan makanan utama berhubungan positif dengan banyaknya menstruasi normal pada remaja putri.

Salah satu pesantren tradisional yang di Kabupaten Malang adalah Pondok Pesantren Nurul Huda yang terletak di Kecamatan Poncokusumo. Pesantren ini tidak jauh berbeda dengan pesantren pada umumnya, jika dilihat dari kondisi kesehatan santri dan menu makan mereka di pesantren. Bahan makanan dipilih dan diolah sendiri oleh para santri putri, dengan tatanan menu 
yang sederhana. Mengingat hingga saat ini kondisi kesehatan di pondok pesantren masih dipandang sebelah mata. Padahal dimasa yang akan datang, santri putri akan menjadi wanita yang melahirkan generasi penerus bangsa.

Tujuan penelitian ini adalah untuk mengetahui hubungan usia menarche dan status gizi dengan siklus menstruasi santri putri di Pondok Pesantren Nurul Huda Kecamatan Poncokusumo Kabupaten Malang.

\section{METODE}

Penelitian ini merupakan jenis penelitian kuantitatif korelasional (correlational studies) dengan pendekatan cross sectional. Penelitian ini dilakukan di Pondok Pesantren Nurul

Huda Kecamatan Poncokusumo Kabupaten Malang dan dilakukan dalam rentang waktu bulan Januari-Maret 2017.

Populasi target dalam penelitian ini adalah keseluruhan santri putri yang berjumlah 93 orang. Sampel diambil dengan teknik purposive sampling. Setelah disesuaikan dengan kriteria inklusi dan eksklusi peneliti, maka jumlah sampel yang diperoleh sebesar 50 orang santri putri.

Kriteria inklusi yaitu: 1) merupakan santri putri Pondok Pesantren Nurul Huda, 2) bermukim/ tinggal di Pondok Pesantren Nurul Huda, 3) telah mengalami menarche minimal selama enam bulan berturut-turut atau sejak bulan Juni 2016, 4) mampu mengingat tanggal pertama menstruasi dalam empat bulan terakhir, 5) bersedia menjadi responden penelitian dengan mengisi form informed consent. Sedangkan kriteria eksklusi yaitu: 1) menderita penyakit reproduksi, 2) sedang menghadapi ujian, 3) merokok dan mengkonsumsi obat hormonal, 4) tidak hadir pada pengambilan data, 5) menolak menjadi responden.

Penelitian ini menggunakan insrumen berupa kuesioner usia menarche dan siklus menstruasi serta lembar pengukuran Indeks Masa Tubuh. Teknik pengumpulan data dari variabel usia menarche adalah dengan wawancara dengan berpedoman kepada kuesioner. Sedangkan data siklus menstruasi diperoleh melalui kuesioner yang diberikan secara langsung kepada responden. Apabila calon responden bersedia, maka responden diminta untuk menandatangani informed consent dan peneliti mem-berikan kuesioner untuk diisi. Selanjut-nya, untuk pengumpulan

data dari variabel status gizi menggunakan teknik pengukuran secara langsung terhadap responden. Peneliti akan memandu responden mengukur tinggi badan dengan microtoise dan mengukur berat badan menggunakan timbangan injak yang telah di kalibrasi.

Setelah dilakukan pengumpulan data maka akan dilanjutkan dengan ananlisis data. Uji analisis bertujuan untuk mengetahui apakah variabel $\mathrm{X}_{1}$ (usia menarche) berpengaruh terhadap variabel Y (siklus menstruasi) dan apakah variabel $\mathrm{X}_{2}$ (status gizi) berpengaruh pada variabel Y (siklus menstruasi). Analisis data pada penelitian ini menggunakan uji alternatif chi-square yaitu uji fisher dengan bantuan software statistik.

\section{Hasil}

Tabel 1. Distribusi Frekuensi Usia Responden

\begin{tabular}{ccc}
\hline Usia & Frekuensi & Persentase \% \\
\hline $11-13$ & 9 & 18,0 \\
$14-16$ & 28 & 36,0 \\
$17-19$ & 13 & 26,0 \\
\hline Total & $\mathbf{5 0}$ & $\mathbf{1 0 0 , 0}$ \\
\hline
\end{tabular}

Usia responden dalam penelitian ini adalah usia remaja 11-19 tahun. Sebagian besar santri putri yang menjadi responden, memiliki usia 15 tahun berjumlah 11 responden dengan persentase sebesar $22 \%$. 


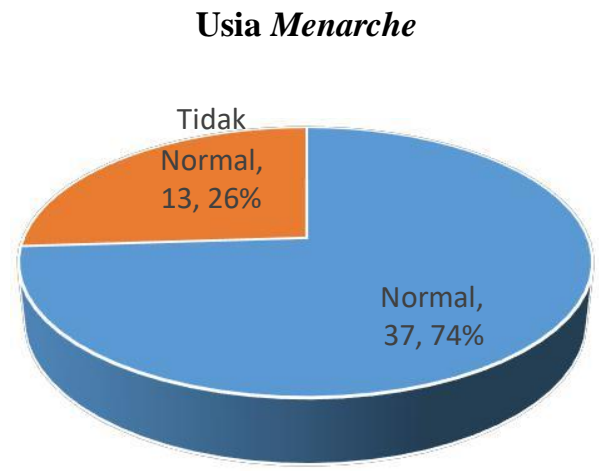

\section{Gambar 1 Diagram Kategori Usia Menarche Responden}

Berdasarkan hasil penelitian menunjukkan bahwa sebagian besar reponden mengalami menarche dalam kategori usia normal (11-13 tahun)

berjumlah 37 responden dengan persentase sebesar $74 \%$. Sedangkan responden yang mengalami menarche dalam kategori usia tidak normal

berjumlah 13 responden dengan persentase sebesar $26 \%$.

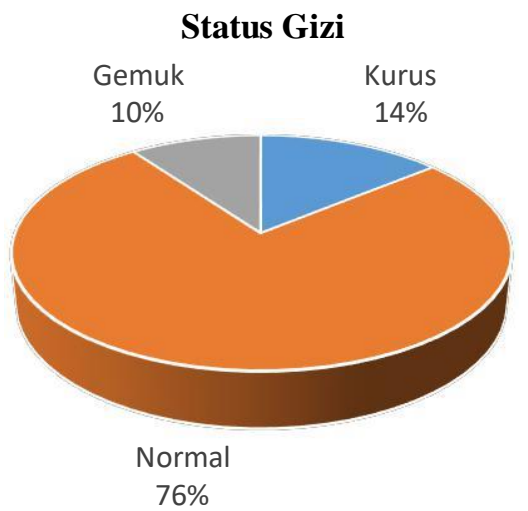

Gambar 2 Diagram Kategori Status Gizi Responden

Berdasarkan hasil penelitian menunjukkan bahwa sebagian besar reponden memiliki status gizi dalam kategori normal berjumlah 38 responden dengan persentase sebesar $76 \%$. Status gizi normal yang dimaksud disini adalah responden yang memiliki berat badan dan tinggi badan normal menurut rumus indeks masa tubuh dalam rentang nilai 18,5-25,0. Responden yang memiliki status gizi kurang (kurus) berjumlah tujuh responden dengan persentase sebesar $14 \%$, sedangkan status gizi lebih (gemuk) berjumlah lima orang dengan persentase sebesar 10\% saja. 


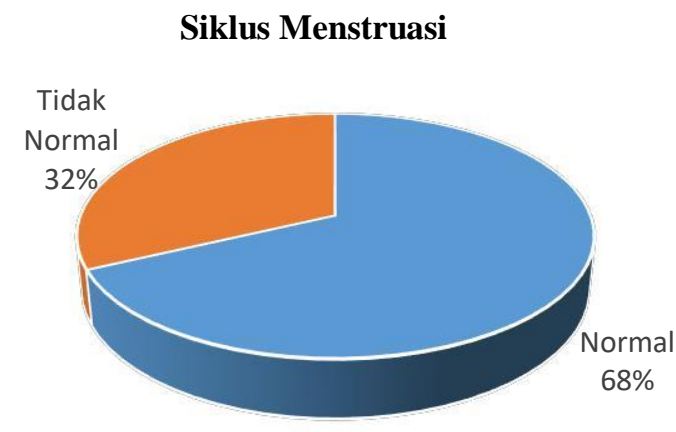

\section{Gambar 3 Diagram Kategori Siklus Menstruasi Responden}

Berdasarkan hasil penelitian menunjukkan bahwa sebagian besar reponden memiliki siklus menstruasi dalam kategori normal (21-35 hari) berjumlah 34 orang dengan persentase sebesar $68 \%$. Sedangkan responden yang memiliki siklus menstruasi tidak normal berjumlah 16 dengan persentase sebesar $32 \%$

saja.

Tabel 5. Hubungan Usia Menarche dengan Siklus Menstruasi

\begin{tabular}{ccccc}
\hline & & \multicolumn{2}{c}{ Siklus Menstruasi } & \\
\cline { 2 - 4 } Usia Menarche & Tidak Normal & Normal & Total \\
\cline { 2 - 4 } Tidak Normal & Count & 7 & 6 & 13 \\
& ExpectedCount & 4,2 & 8,8 & 13,0 \\
& $\%$ & $14 \%$ & $12 \%$ & $26 \%$ \\
Normal & & & \\
& Count & 9 & 28 & 37 \\
& Expected Count & 11,8 & 25,2 & 37,0 \\
& $\%$ & $18 \%$ & $56 \%$ & $74 \%$ \\
& & & & \\
\hline Total & Count & 16 & 34 & 50 \\
& Expected Count & 16,0 & 34,0 & 50,0 \\
& $\%$ & $32 \%$ & $68 \%$ & $100 \%$ \\
\hline
\end{tabular}

Tabel 6. Hubungan Status Gizi dengan Siklus Menstruasi

\begin{tabular}{|c|c|c|c|c|}
\hline \multirow{2}{*}{\multicolumn{2}{|c|}{ Status Gizi }} & \multicolumn{2}{|c|}{ Siklus Menstruasi } & \multirow[b]{2}{*}{ Total } \\
\hline & & \multirow{2}{*}{$\begin{array}{c}\text { Tidak Normal } \\
9\end{array}$} & \multirow{2}{*}{$\frac{\text { Normal }}{3}$} & \\
\hline Tidak Normal & Count & & & 12 \\
\hline (Kurus \& & Expected Count & 3,8 & 8,2 & 12,0 \\
\hline Gemuk) & $\%$ & $18 \%$ & $6 \%$ & $24 \%$ \\
\hline \multirow[t]{3}{*}{ Normal } & Count & 7 & 31 & 38 \\
\hline & Expected Count & 12,2 & 25,8 & 38,0 \\
\hline & $\%$ & $14 \%$ & $62 \%$ & $76 \%$ \\
\hline \multirow[t]{3}{*}{ Total } & Count & 16 & 34 & 50 \\
\hline & Expected Count & 16,0 & 34,0 & 50,0 \\
\hline & $\%$ & $32,0 \%$ & $68,0 \%$ & $100 \%$ \\
\hline
\end{tabular}


Analisis variabel independen (usia menarche dan status gizi dengan variabel dependen (siklus menstruasi) menggunakan uji chi-square tabel $2 \times 2$ ternyata tidak memenuhi syarat, yaitu sel yang mempunyai nilai expected kurang dari 5 , maksimal $20 \%$ dari jumlah sel. Maka dari itu dilakukan alternatif uji chisquare yaitu uji Fisher.

\section{PEMBAHASAN}

\section{Usia Menarche}

Hasil penelitian menunjukkan

bahwa sebagian besar reponden mengalami menarche dalam kategori usia normal (11-13 tahun) berjumlah 37 (74\%) sedangkan dalam kategori tidak normal berjumlah 13 (26\%). Hasil penelitian ini sejalan dengan hasil penelitian yang dilakukan oleh Gustina (2013) pada remaja putri di Surakarta yang menunjuk-kan bahwa responden mengalami usia menarche paling banyak yaitu pada usia 12 tahun.

Juliyatmi \& Handayani (2015) menyatakan bahwa mayoritas siswi SMP yang menjadi responden pada penelitiannya memiliki usia menarche yang normal. Kategori normal adalah menarche yang dialami oleh responden antara usia 11-13 tahun. Di sisi lain, dinyatakan termasuk pada kategori usia menarche tidak normal adalah menarche yang dialami oleh responden pada usia $<11$ tahun dan >13 tahun. Menurut Prawirohardjo (2009) usia gadis remaja saat mengalami menstruasi untuk pertama kalinya (menarche) memiliki variasi yang lebar, tetapi rata-rata adalah 12,5 tahun. Statistik menunjukkan bahwa usia menarche dipengaruhi oleh beberapa faktor, meliputi faktor keturunan, keadaan gizi dan kesehatan umum.

Sebagian besar santri putri yang masuk dalam kategori usia menarche tidak normal, adalah mereka yang mengalami menstruasi pertama kali dalam rentang usia 14 tahun keatas. Hal ini sejalan dengan penelitian yang dilaksanakan oleh Emilia dkk (2013) dimana hasil penelitian menunjukkan bahwa remaja putri di desa mengalami menstruasi pertama kali pada rentang usia 13,8 tahun. Gangguan menarche ini disebut menarche tarda dimana menarche yang baru datang setelah umur 14 tahun. Pubertas dianggap terlambat jika gejalagejala pubertas baru datang antara umur 14-16 tahun. Pubertas tarda dapat disebabkan oleh faktor herediter, gangguan kesehatan, dan kekurangan gizi (Wiknjosastro, dalam Rohmatika dkk, 2012).

\section{Status Gizi}

Hasil penelitian melalui perhitungan dengan rumus indeks massa tubuh, menunjukkan bahwa sebagian besar reponden memiliki status gizi dalam kategori normal (IMT 18,5-25,0) dengan jumlah 38 orang $(76 \%)$, sedangkan responden yang memiliki status gizi kurus berjumlah 7 orang (14\%) dan status gizi gemuk berjumlah 5 orang (10\%). Hasil penelitian ini sejalan dengan hasil penelitian yang dilakukan oleh Amelia, dkk (2013) didapatkat hasil sebagian besar status gizi santri termasuk dalam kategori normal.

Menurut Dieny (2014) terdapat dua faktor yang mempengaruhi status gizi, yaitu faktor penyebab langsung dan tidak langsung. Faktor penyebab langsung adalah asupan makan dan penyakit infeksi. Sedangkan faktor penyebab tidak langsung yaitu aktivitas fisik, faktor individu, faktor keluarga, lingkungan sekolah dan teman sebaya, tingkat sosial dan ekonomi dan media massa.

Penelitian yang dilakukan oleh Pulungan (2009) mendapatkan hasil bahwa tingkat sosial ekonomi secara langsung akan mempengaruhi status gizi anak. Berdasarkan hasil statistik, ternyata faktor tingkat sosial ekonomi responden mempunyai hubungan yang signifikan dengan status gizi responden $(\mathrm{p}<0,05)$. Oleh karena itu untuk memenuhi status gizi yang baik, kedua orangtua responden harus memiliki ilmu yang cukup. Diperlukan tingkat pendidikan dan pekerjaan yang baik dari kedua orangtua responden untuk memperoleh 
penghasilan yang memadai dalam memenuhi asupan gizi keluarga.

Pola makan santri putri disesuaikan dengan pola kehidupan di Pondok Pesantren Nurul Huda. Selama berada di pondok, yang bertindak sebagai orangtua adalah pengurus pondok pesantren. Santri putri diharuskan mempersiapkan menu makanan mereka sendiri, mulai dari berbelanja bahan makanan hingga memasak untuk para santri di pondok. Menu yang disiapkan sangat sederhana dengan komponen nasi, sayur, dan lauk pauk sederhana. Hal ini kemungkinan besar dipengaruhi oleh lingkungan pondok yang masih berada di daerah pedesaan, yang sebagian besar penduduknya memiliki ekonomi menengah ke bawah.

\section{Siklus Menstruasi}

Berdasarkan hasil penelitian diperoleh bahwa sebagian besar reponden memiliki siklus menstruasi dalam kategori normal (21-35 hari) berjumlah 34 responden dengan persentase sebesar $68 \%$ sedangkan dalam kategori tidak normal ( $<21$ hari dan $>35$ hari) berjumlah 16 orang (32\%). Hasil penelitian ini sesuai dengan hasil penelitian yang

dilakukan Puspitaningtyas (2014) diperoleh hasil siswi remaja putri sebagian besar mengalami siklus menstruasi normal (21-35 hari). Namun hasil penelitian ini berbeda dengan penelitian yang dilakukan oleh Putri (2015) bahwa dari hasil penelitian dimana remaja dengan siklus menstruasi yang teratur lebih sedikit daripada remaja dengan siklus menstruasi tidak teratur.

Menurut pendapat Attarchi (2013) siklus menstruasi yang teratur adalah siklus menstruasi yang berada dalam interval 23-35 hari dengan perbedaan maksimum 7 hari antara siklus menstruasi yang terpendek dan yang terpanjang. Sedangkan menurut konsep teori Maryanti \& Septikasari (2009), pan-jang siklus menstruasi yang normal adalah 21-35 hari dan rata-rata 28 hari. Jika siklusnya kurang dari 21 hari atau lebih dari 35 hari dan tidak teratur, biasanya siklusnya anovulatoir (Kurniawati, 2009). Anovulatoir adalah kondisi dimana terdapat kemungkinan setiap siklusnya tidak disertai dengan ovulasi, biasanya siklus terjadi kurang dari 18 hari atau lebih dari 42 hari (Ramadhy, 2011).

Siklus menstruasi ini sangat bervariasi, tidak hanya antar wanita dalam setiap individunya, bahkan sekalipun kembar identik memiliki kemungkinan siklusnya berbeda. Faktor yang mem-pengaruhi siklus menstruasi menurut Bobak (2004) diantaranya yaitu usia wanita, status fisik, emosi, serta ling-kungan.

Berdasarkan data Analisis dan Interpretasi Data pada Pondok Pesantren, Madrasah Diniyah (Madin), Taman Pendidikan Qur'an (TPQ) Tahun Pelajaran 2011-2012 oleh Kementerian Agama RI, dapat disimpulkan bahwa hampir seluruh santri yang mendapat pendidikan di pondok pesantren adalah santri yang bermukim $(79,93 \%)$. Hal ini dikarenakan memang dalam pembelajaran di pondok pesantren, waktu belajar adalah hampir 24 jam penuh. Aktivitas yang dilakukan oleh santri putri selama berada di pondok pesantren dapat mempengaruhi kondisi fisik dan dapat mengganggu kondisi psikologis pada santri putri.

Hal ini didukung oleh hasil penelitian yang dilakukan oleh Parawita (2014) menyatakan bahwa teratur atau tidaknya lama menstruasi bisa dipengaruhi oleh beberapa faktor, salah satunya yaitu faktor aktivitas remaja yang berlebih sehingga mengakibatkan stres yang bisa menjadikan lama menstruasi tidak menentu. Lama menstruasi yang terlalu panjang bisa menandakan adanya suatu penyakit pada diri remaja tersebut. Peryataan tersebut sejalan dengan Richard et al. (2006) yang menyatakan bahwa siklus menstruasi memang memiliki variabilitas, jika melebihi siklus normal mungkin

mengindikasikan bahwa ter-dapat masalah kesehatan. 


\section{Hubungan Usia Menarche dengan Siklus Mensruasi}

Setelah dilakukan analisis statistik dengan uji Fisher diperoleh nilai $p=0,082$ (dengan nilai $\alpha>0,05$ ) maka, $p$ $>\alpha$ sehingga Ho diterima dan Ha ditolak sehingga, tidak ada hubungan yang signifikan antara usia menarche dengan siklus menstruasi santri putri di Pondok Pesantren Nurul Huda. Diperoleh bahwa responden yang mempunyai usia menarche tidak normal dengan siklus menstruasi normal sebanyak 6 responden (12\%), sedangkan responden yang mempunyai usia menarche normal dengan siklus menstruasi tidak normal sebanyak sembilan responden (18\%).

Hasil penelitian ini sejalan dengan penelitian yang dilakukan oleh Fatimah (2015) dan Putri (2015) dimana setelah dilakukan ananilisis maka didapatkan kesimpulan bahwa tidak ada hubungan usia menarche dengan siklus menstruasi. Hal ini didukung oleh temuan dalam penelitian Sonia et al. (2014), dimana tidak terdapat hubungan yang signifikan secara statistik antara usia menarche dan siklus menstruasi.

Hasil tersebut kemungkinan menunjukkan bahwa hubungan usia menarche dan siklus menstruasi pada remaja disebabkan oleh banyak faktor. Jumlah responden yang terlalu sedikit, metodesampling,danmetode

pengumpulan data bisa menjadi keterbatasan yang dapat mempengaruhi hasil penelitian.

Banyak faktor lain yang berpengaruh pada siklus menstruasi santri putri, salah satunya adalah faktor hormonal serta interaksi sosial dan lingkungan (Kusmiran, 2012). Ke-giatan santri putri yang sangat padat bisa memicu munculnya stres pada santri putri sehingga berpengaruh terhadap sistem hormonal tubuh. Stres akan menyebabkan perubahan sistemik tubuh,

khususnya sistem syaraf dalam hipotalamus.

Adanya gangguan hormonal dari tubuh akan berpengaruh pada organ tubuh,termasuk organ seksual perempuan baik berupa peningkatan progesteron, esterogen, Luteinizing Hormon (LH) dan Follice Stimulating Hormon (FSH) sendiri, yang akan berdampak pada gangguan sikus menstruasi yang terlalu cepat atau pendek begitupun sebaliknya (Proverati \& Asfuah, 2009). Selain itu, Kusmiran (2012) menyebutkan bahwa interaksi manusia dengan ling-kungannya merupakan siklus yang sinkron. Proses

interaksi tersebut ternyata juga melibatkan sistem hormonal, salah satunya adalah hormon reproduksi. Adanya pherohormon yang dikeluarkan setiap individu dapat mempengaruhi individu lain, serta dapat menurunkan variabilitas siklus menstruasi. Hal ini kemungkinan besar berpengaruh terhadap siklus menstruasi santri putri karena setiap harinya akan terjadi interaksi dengan sesama santri putri dalam rentang waktu hampir 24 jam.

Sehingga dengan adanya faktorfaktor lain yang telah dijelaskan tersebut, usia menarche santri putri bisa dikatakan sebagai salah satu indikator yang tidak memiliki berhubungan dengan siklus menstruasi. Hal ini dibuktikan dengan hasil analisis penelitian bahwa ternyata tidak ada hubungan yang signifikan antara usia menarche dengan siklus menstruasi santri putri di Pondok Pesantren Nurul Huda Kecamatan Poncokusumo Kabu-paten Malang.

\section{Hubungan Status Gizi dengan Siklus Menstruasi Santri Putri}

Berdasarkan analisis yang dilakukan menggunakan uji Fisher, diperoleh hasil nilai $p=0,001$ (dengan nilai $\alpha=0,05)$ maka $p<\alpha$ sehingga Ho ditolak dan Ha diterima, dapat ditarik

kesimpulan ada hubungan yang signifikan antara status gizi dengan siklus menstruasi santri putri di Pondok Pesantren Nurul Huda. Diketahui responden yang mempunyai status gizi normal dengan siklus menstruasi normal sebanyak 31 responden (62\%) sedangkan responden yang mempunyai status gizi tidak normal dengan siklus menstruasi tidak normal sebanyak 9 responden (18\%). 
Hasil penelitian ini sejalan dengan penelitian yang dilaksanakan oleh Noviandari (2016) yaitu terdapat hubungan antara status gizi dengan siklus menstruasi pada remaja putri. Dieny (2014) mengatakan bahwa status gizi berperan penting dalam mempengaruhi fungsi organ reproduksi. Selama ini telah diketahui bahwa remaja yang memiliki status gizi kurang memiliki resiko terjadinya gangguan siklus menstruasi yang diakibatkan oleh terganggunya pertumbuhan dan perkembangan sistem reproduksi. Akan tetapi, gangguan siklus menstruasi juga ditemukan pada remaja dengan status gizi lebih. Hal ini dikaitkan dengan jumlah jaringan lemak tubuh. Pernyataan ini didukung oleh hasil penelitian Pratiwi (2011) bahwa sebagian besar responden yang memiliki siklus menstruasi teratur adalah kelompok siswi dengan status gizi normal dan siswi yang mengalami siklus menstruasi tidak teratur adalah kelompok siswi dengan status gizi kurus.

Menurut hasil penelitian Sheetal et al. (2015) menunjukkan bahwa remaja perempuan yang memiliki berat badan lebih dan obesitas memiliki siklus menstruasi yang tidak teratur yang disebut dengan oligomenorea. Kondisi tersebut sejalan dengan pendapat Proverawati dan Asfuah (2009) bahwa status gizi berlebih seperti gemuk dan obesitas akan berdampak pada fungsi sistem hormonal tubuh, mengingat bahwa lemak mampu memproduksi

esterogen yang meng-akibatkan gangguan siklus menstruasi. Bentuk gangguan menstruasi bermacam- macam. Status gizi akan mempengaruhi fungsi kerja hormonal, berupa pening-katan, keseimbangan ataupun penurunan. Status gizi sendiri dipengaruhi oleh banyak faktor, pada umumnya adalah pola makan yang tidak seimbang.

Perubahan status gizi dapat berdampak pada perubahan siklus hormonal reproduksi yang berhubungan langsung dengan kelebihan lemak tubuh, obesitas pada bagian perut, serta gangguan ovulasi dan hiperandrogisme. Hipotesis dari para ilmuan bahwa munculnya menstruasi dipengaruhi oleh lemak tubuh dikaitkan dengan berat badan tubuh total. Fungsi menstruasi sangat bergantung dengan presentase lemak tubuh. Presentase yang dibutuhkan untuk menjaga keteraturan menstruasi berikutnya adalah sekitar 22\% (Dieny, 2014). Jika dilihat dari pola makan dan menu yang tersedia untuk para santri putri di Pondok Pesantren Nurul Huda, maka menu yang tersedia belum dapat dikatakan sebagai menu seimbang. Menu yang disediakan sangat sederhana dan tidak ada pengaturan menu setiap harinya. Gambaran pola makan di Pondok Pesantren Nurul Huda dapat dikatakan sama dengan beberapa poin hasil penelitian Purwaningtyas (2013) pada pesantren Al-Qodiri di Kabupaten Jember yaitu dapat disimpulkan bahwa semua unit penyelenggaraan makan di pondok pesantren tidak mempunyai siklus menu dan pengadaan bahan makanan semua unit penyelenggaraan makan dibeli langsung ke pasar.

Penelitian yang dilakukan oleh Amelia dkk (2013) mengenai status gizi santri putri, hasil penelitian menunjukkan bahwa asupan zat gizi makro, asupan lemak santri sebagian besar termasuk dalam kategori cukup, asupan karbohidrat dan zat gizi mikro santri sebagian besar termasuk dalam kategori kurang jika dibandingkan dengan Angka Kecukupan Gizi (AKG). Menurut Kusmiran (2012) vegetarian (hanya mengkonsumsi makanan dari tumbuhan tanpa mengkonsumsi makanan hewani) berhubungan erat dengan terjadinya anovulasi, penurunan respon hormon pituitari, fase folikel yang pendek, tidak normalnya siklus menstruasi. Kekurangan lemak berpengaruh terhadap panjangnya siklus menstruasi dan lama periode perdarahan.

\section{KESIMPULAN}

Dari data hasil dan pembahasan yang telah disajikan dapat disimpulkan sebagai berikut:

1) Sebagian besar santri putri di Pondok Pesantren Nurul Huda Kecamatan Poncokusumo Kabupaten Malang, 
mengalami menarche dalam kategori usia normal (11-13 tahun) berjumlah 37 orang $(74 \%)$, memiliki status gizi dalam kategori normal (IMT 18,5$25,0)$ berjumlah 38 orang $(76 \%)$, dan memiliki siklus menstruasi dalam kategori normal (21-35 hari) berjumlah 34 orang $(68 \%)$.

2) Tidak ada hubungan yang signifikan antara usia menarche dengan siklus menstruasi santri putri di Pondok Pesantren Nurul Huda Kecamatan Poncokusumo Kabupaten Malang, diketahui nilai $p$-value $=0,082(\alpha=$ $0,05)$, serta ada hubungan yang signifikan antara status gizi dengan siklus menstruasi santri putri di Pondok Pesantren Nurul Huda Kecamatan Poncokusumo Kabupaten Malang, diketahui $p$-value $=0,001(\alpha$ $=0,05$ ).

\section{SARAN}

Berdasarkan hasil penelitian dan kesimpulan di atas, maka dapat dikemukakan saran-saran sebagai berikut:

1) Bagi Praktisi Kesehatan Masyarakat Hendaknya mampu melakukan kajian dan analisis pada masalah-masalah kesehatan yang mungkin muncul pada remaja saat ini. Serta dapat mengembangkan media promosi kesehatan bagi para remaja untuk memberikan informasi aktual berkaitan dengan gizi dan kesehatan reproduksi.

2) Bagi Pondok Pesantren Nurul Huda Pengelola pondok pesantren

hendaknya memberikan perhatian yang lebih terhadap kondisi pemenuhan gizi bagi santri putri. Perlu adanya penambahan menu makanan berupa protein dan lemak hewani demi tercukupinya gizi para santri putri. Perlu adanya kegiatan konseling kesehatan untuk mengurangi kemungkinan terjadinya stres pada santri putri.

3) Bagi Responden

Bagi santri putri yang memiliki status gizi dan siklus menstruasi normal diharapkan dapat menjaga kondisi kesehatannya, dan yang tidak normal diharapkan dapat menjaga asupan gizi yang dikonsumsinya. Santri putri perlu memperbaiki tatanan menu makanan agar gizi mereka tercukupi.

4) Bagi Peneliti Selanjutnya

Hasil penelitian ini dapat dijadikan sebagai dasar acuan untuk pengembangan lebih lanjut dengan variabel yang lebih bervariasi. Penelitian mengenai faktor-faktor lain yang

kemungkinan besar berpengaruh terhadap siklus menstruasi (faktor

genetik, hormon, aktivitas fisik, lingkungan, dan lain sebagainya), terutama pada faktor aktivitas fisik.

\section{DAFTAR RUJUKAN}

Ali, et al. 2011. Age at Menarche and Menstrual Cycle Pattern Among Schoolgirls in Kassala in Eastern Sudan. Journal of Public Health and Epidemiology, 3(3): 111-114.

Almatsier, S. 2010. Prinsip Dasar Ilmu Gizi. Jakarta: PT. Gramedia Pustaka Utama.

Amelia, A.R, dkk. 2013. Hubungan Asupan Energi Dan Zat Gizi Dengan Status Gizi Santri Putri Yayasan Pondok Pesantren Hidayatullah Makassar Sulawesi Selatan Tahun 2013. Skripsi Tidak Diterbitkan. Universitas Hasanuddin Makassar.

Attarchi, et al. 2013. Characteristics of Menstrual Cycle in Shift Workers. Global Journal of Health Science, 5( 3): 163-172.

Bobak, I.M., et al. 2005. Buku Ajar Keperawatan Maternitas (Maternity Nursing) Edisi 4. Jakarta: EGC.

Derina, K.A. 2011. Laporan Penelitian: Faktor-Faktor yang Berhubungan dengan Usia Menars Pada Remaja Putri di SMPN 155 Jakarta Tahun 2011. Fakultas Kedokteran Dan Ilmu Kesehatan Uin Syarif Hidayatullah.

Dieny, F. F. 2014. Permasalahan Gizi Pada Remaja Putri. Yogyakarta: Graha Ilmu.

Emilia, E. 2008. Pengetahuan, Sikap, dan Praktek Gizi pada Remaja. 
Tesis Tidak diterbitkan. Bogor: Sekolah Pasca Sarjana Insitut Pertanian Bogor.

Emilia, S.L. dkk. 2013. Perbandingan Usia Menars Dan Pola Siklus Menstruasi Antara Remaja Putri Di Kota Dan Desa (SMP Negeri 6 Makassar Dan SMP Negeri 11 Bulukumba) Di Sulawesi Selatan Tahun 2013. Journal Kesehatan Masyarakat. Universitas Hasanudin Makasar.

Fatimah, D,W. 2015. Hubungan usia menarche dengan siklus menstruasi pada remaja di SMP Negeri 29 Semarang. Skripsi Tidak Diterbit-kan. Universitas Muhammadiyah Semarang.

Global Nutrition Report. 2014. (Online)(www.schoolsandhealth.or g/.../Global\%20Nutrition\%20Repo rt.pdf), diakses tanggal 30 Oktober 2016.

Gustina, T. 2013. Hubungan Antara Usia Menarche Dan Lama Menstruasi Dengan Kejadian Dismenore Primer Pada Remaja Putri Di SMK Negeri 4 Surakarta. Skripsi tidak diterbitkan. Universitas Muham-madiyah Surakarta.

Juliyatmi, R .H. \& Handayani, L. 2015. Nutritional Status and Age at Menarche on Female Students of Junior High School. International Journal of Evaluation and Research in Education (IJERE). 4(2) : 71-75.

diterbitkan. Universitas Muhammadiyah Jember.

Pratiwi, A. 2011. Hubungan Status Gizi

Dengan Keteraturan Siklus Menstruasi Siswi SMA Negeri 1 Mojolaban. Skripsi diterbitkan. Surakarta: Universitas Sebelas Maret. Prawirohardjo, S. 2009. Ilmu Kandungan. Jakarta: P.T.

Bina Pustaka Sarwono Prawirohardjo.

Yogyakarta: Nuha Medika.

Proverawati, A. \& Asfuah, S. 2009. Buku Ajar Gizi untuk Kebidanan. Yogyakarta: Nuha Medika.
Kemenag. 2012. Analisis dan Interpretasi Data pada Pondok Pesantren, Madrasah Diniyah (Madin), Taman Pendidikan Qur'an (TPQ) Tahun Pelajaran 2011-2012olehKementerian

Agama RI. (Online) (pendis.kemenag.go.id/file/dokum en/pontrenanalisis.pdf), diakses tanggal 6 Januari 2017.

Kurniawati, D. \& Hanifah. 2009. Obgynacea. Yogyakarta: TOSCA Enterprise.

Kusmiran, E. 2012. Kesehatan Reproduksi Remaja Dan Wanita. Jakarta: Salemba Medika.

Maryanti, D \& Septikasari, M. 2009. Buku Ajar Kesehatan Reproduksi Teori dan Praktikum. Yogyakarta: Nuha Medika.

Noviandari, I. 2016. Hubungan Antara Status Gizi Dan Anemia Dengan Siklus Menstruasi Pada Remaja Putri Di Sma Batik 1 Surakarta.

Naskah Publikasi. Universitas Muhammadiyah Surakarta.

Nugroho, T \& Utama, B.I. 2014. Masalah Kesehatan Reproduksi Wanita. Yogyakarta: Nuha Medika.

Paath,F., dkk. 2005. Gizi dalam Kesehatan Reproduksi. Jakarta; EGC.

Parawita, N.I. 2014. Hubungan Tingkat Stres Dengan Siklus Menstruasi Pada Mahasiswi Fakultas Ilmu Kesehatan Di Universitas Muhammadiyah Jember. Skripsi tidak

Pulungan, P.W. 2009. Gambaran Usia Menarche Pada Remaja Putri di SMP Shafiyyatul Amaliyah dan SMP Nurul Hasanah Kota Medan Tahun 2009. Skripsi tidak diterbitkan. Universitas Sumatera Utara.

Purwaningtyas, S. 2013. Gambaran Penyelenggaraan Makan Di Pondok Pesantren Al-Qodiri Kabupaten Jember. Skripsi tidak diterbitkan. Universitas Negeri Jember.

Puspitaningtyas, D.I. 2014. Hubungan antara status gizi dengan siklus 
menstruasi pada remaja putri di SMA N 2 Surakarta. Skripsi tidak diterbitkan. Universitas Sebelas Maret Surakarta.

Putri, G. 2015. Hubungan Usia Saat Menarche dan Dismenorea dengan Pola Siklus Menstruasi Remaja Putri di SMP Shafiyyatul Amaliyyah Medan. Skripsi tidak diterbitkan. Universitas Sumatera Utara.

Ramadhy, A.S. 2011. Biologi Reproduksi. Bandung: PT Refika Aditama.

Richard J.F., et al. 2006. Variability in the Phases of the Menstrual Cycle. Journal of Obstetric, Gynecologic, and Neonatal Nursing, 35(3): 376384.

RIKESDAS. 200. Riset Kesehatan Dasar. Jakarta: RIKESDA

Rizki, N. 2015. Hubungan Status Gizi Dengan Siklus Menstruasi Pada Remaja Putri Kelas Xi Di Smk N 4 Yogyakarta. Naskah Publikasi. Stikes Aisyiyah Yogyakarta

Rofieq, A. 2012. Pola Adopsi Perilaku Kesehatan Santri Mukim pada Pondok Pesantren. Skripsi Tidak Diterbitkan. Universitas Muhammadiyah Malang.

Rohmatilah, D., Sumarni., \& Pranbandari, F. 2012. Pengaruh
Usia Menarche Terhadap Usia

Menopause Pada Wanita

Menopause Di Desa Jingkang

Babakan Kacamatan Ajibarang Kabupaten Banyumas Tahun 2012. Jurnal Ilmiah Kebidanan, 3(2): 89-100.

Sheetal, B. et al. 2015. Influence of Body Mass Index on Menstrual Irregularities in Adolescent girls. International Journal of Medical and Health Sciences, 4(2): 213-216.

Sonia, I.O, et al. 2014. Body Mass Index Influences the age at Menarche and Duration of Menstrual Cycle. American Journal of Health Research, 2(5): 310-315.

Sutardji \& Azinar, M. 2007. Tingkat Konsumsi Energi Dan Konsumsi Protein Serta Hubungannya Dengan Status Gizi Anak Asuh Usia 10-18 Tahun (Studi Pada Penyelenggaraan Makanan Di Panti Asuhan Pamardi Putra

Kabupaten Demak). Jurnal Kesehatan Masyarakat, 2(2): 162174.

Widyastuti, Y., dkk. 2011. Kesehatan Reproduksi. Yogyakarta: Fitramaya. 